\title{
CHLORINE PRODUCTION FOR WATER DISINFECTION BY THE MEANS OF PHOTOVOLTAIC PANELS
}

\author{
STANISLAV HOSTIN ${ }^{1}$, PETER BENEDIKOVIČ ${ }^{2}$, \\ ANNA MICHALÍKOVÁ2 \\ ${ }^{1}$ Department of Biotechnology, University of SS. Cyril and Methodius, J. Herdu 2, \\ Trnava, SK-917 01, Slovak Republic (stanislav.hostin@ucm.sk) \\ ${ }^{2}$ Slovak University of Technology in Bratislava, Faculty of Materials Science and \\ Technology in Trnava, Institute of Safety and Environmental Engineering, \\ Department of Environmental Engineering, Botanická 49, Trnava, SK-917 08, Slovak \\ Republic (anna.michalikova@stuba.sk)
}

\begin{abstract}
In this contribution a possibility of electrochemical production of chlorine for water disinfection, by using photovoltaic panels from solar energy, is described. A simple way of chloride production by means of a photovoltaic panel, comparable with classical electrical power source was performed on an experimental device. By using photovoltaic panel with nominal output $50 \mathrm{~W}$ and solar irrigation $380-$ $550 \mathrm{~W} / \mathrm{m}^{2}$ chlorine production was $0.3 \mathrm{mg} / \mathrm{min}$, which represents amount of chlorine sufficient for disinfections of approximately 40001 water per day.
\end{abstract}

Key words: chlorine production, disinfection of water, solar energy, photovoltaic panel

\section{Introduction}

Water disinfection is important to provide for a hygienic quality of water. It is not only a concern of drinking, service, heating and cooling waters in industry but also waters for public and private pools. In all these cases a potential infection with pathogenic micro-organism Legionella pneumophilla must be prevented. Water disinfection must be acceptable from point of view of environmental impacts, efficiency and costs (VERČIMÁKOVÁ et al., 2008).

A broad scale of disinfection agents and techniques are available. Each of them have advantages and disadvantages. For disinfection of drinking water chlorine, chlordioxide, ozone, cationic silver particles, UV light and ultrafiltration are the most frequently used. To prepare service water, for example for pools, chlorine, calcium hypochlorite (pellets, solution), sodium hypochlorite (solution produced by electrolysis of sodium chloride), bromine, peroxide, iodine, silver, trichlorisocyuronic acid can be used (BARTRAM et al., 2005).

A frequent way of chlorine production is electrolysis of sodium/potassium chloride solutions. During this process sodium/potassium hydroxide are also produced. The main technologies are mercury, diaphragmatic and membrane electrolysis. In these procedures the base material is mainly sodium chloride or less frequently potassium chloride. Each of the mentioned technologies represents a different way of chlorine 
accumulation that is produced in the space near anode and hydrogen and hydroxide accumulation produced nearby cathode (REED, 2004).

For the diaphragmatic method, which was used in this work, a summary chemical reaction of electrolysis of sodium chloride can be written as follows:

$$
2 \mathrm{NaCl}+2 \mathrm{H}_{2} \mathrm{O} \rightarrow \mathrm{Cl}_{2}+2 \mathrm{NaOH}+\mathrm{H}_{2}
$$

Photovoltaic panels (PV panels) represent nowadays modern and available devices for a direct production of electric energy from the solar source. Principles, materials, properties, types of PV panels are described in many foreign and native publications where various applications in industry and household are presented (APPLEYARD, 2009; ĎURICOVÁ et al., 2008).

In this work we describe an application of PV panels for electrochemical production of chlorine which is subsequently used for disinfection, preferably service water.

\section{Material and methods}

\subsection{Chlorine production}

A hermetic cell (electrolyzer) containing a carbon $\left(6 \mathrm{~cm}^{2}\right.$ area) and an iron $\left(15 \mathrm{~cm}^{2}\right.$ area) with a final volume $750 \mathrm{ml}$ was constructed (Fig. 1). An asbestine diaphragm was localized inside of the cell, $500 \mathrm{ml}$ of a brine containing $7 \% \mathrm{NaCl}$ was used as an electrolyte. The hermetic cell contained two outlets provided with plastic tubes. One outlet served for releasing of hydrogen into atmosphere, chlorine was collected into a beaker containing $500 \mathrm{ml}$ water using a second outlet. Electrolyser was connected to electric circuit according to a scheme presented in Fig. 2. In the first series of experiments a variable laboratory source of unidirectional current type UHS 401-1 (AC $220 \mathrm{~V}, 2 \mathrm{~A} / \mathrm{DC} 1 \ldots .15 \mathrm{~V}, 4 \mathrm{~A}$ ) was used.

A photovoltaic (PV) panel, model STR $36 \times 50$, produced by SOLATEC, Ltd., Czech republic was used as a provider of solar energy. PV panel was localized on a south-west oriented flat roof under $35^{\circ}$ angle. The panel of $1005 \times 453 \times 34 \mathrm{~mm}$ size, $5.9 \mathrm{~kg}$ mass was constructed from a monocrystalline silicium, contained 36 primary cells, working temperature $-35-85{ }^{\circ} \mathrm{C}$. Electric parameters for solar irradiation: $1000 \mathrm{~W} / \mathrm{m}^{2}$, spectrum AM 1.56 , temperature $25{ }^{\circ} \mathrm{C}$, nominal output $50 \mathrm{~W}$, optimal output $50 \mathrm{~W}$, nominal voltage $12 \mathrm{~V}$, optimal voltage $17.4 \mathrm{~V}$, off-load voltage $21.4 \mathrm{~V}$, short circuit current 3.27 A, optimal current 2.97 A.

Electric characteristics of electrolysis (voltage, current) were monitored using wattmeter LUTRON DW 6090 connected via a serial boundary to PC. In case of PV panel, a rheostat with cylindrical coil, total resistance $100 \Omega$ for maximum voltage $500 \mathrm{~V}$ and current $3 \mathrm{~A}$, was used.

\subsection{Determination of chlorine concentration in water}

Concentration of chlorine soluble in water during chlorination was determined spectrophotometrically according to (JONSON and OVERBY, 1969). A yellow- 
orange color of a reaction product of chlorine and o-tholuidine was measured at 440 $\mathrm{nm}$ on a digital spectrophotometer GENESYS ${ }^{T M} 8$ connected to PC. A mixture of $\mathrm{K}_{2} \mathrm{Cr}_{2} \mathrm{O}_{7}$ and $\mathrm{K}_{2} \mathrm{CrO}_{4}$ was used as a calibration curve.

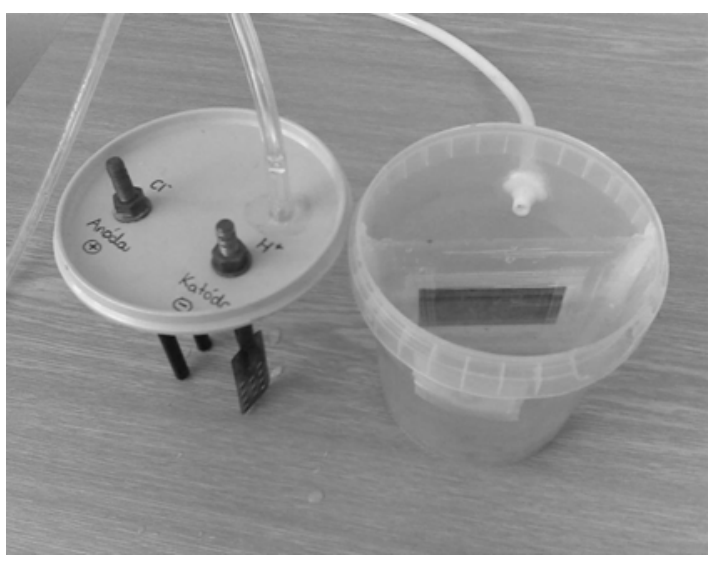

Fig. 1. A hermetic electrolytic cell for chlorine production.

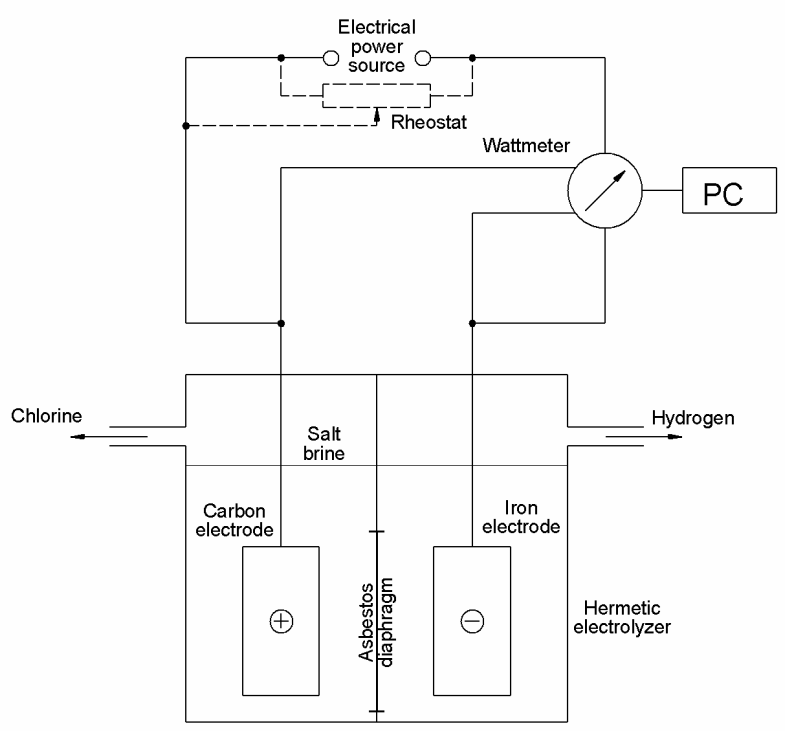

Fig. 2. A scheme of connection of a hermetic cell for chlorine production.

\subsection{Determination of solar irradiation}

This was done by an indicator of intensity of solar irradiation, type FL A613-GS, localized nearby the PV panel connected to the data logger ALMENO 5690-1M (Ahlborn). 


\section{Results and discussion}

\subsection{Study of chlorine production using a laboratory electric power source}

In the first series of experiments a hermetic electrolytic cell was connected to a regulated laboratory electric power source and an electro-chemical production of chlorine was tested. Optimal electric characteristics of electrolysis were determined as a constant voltage $6 \mathrm{~V}$ and current $0.6 \mathrm{~A}$. Fig. 3 presents results of water chlorination. It was found that maximal concentration of chlorine in water was $4.2 \mathrm{mg} / \mathrm{dm}^{3}$ and this was achieved after 25 minutes of electrochemical chlorine production.

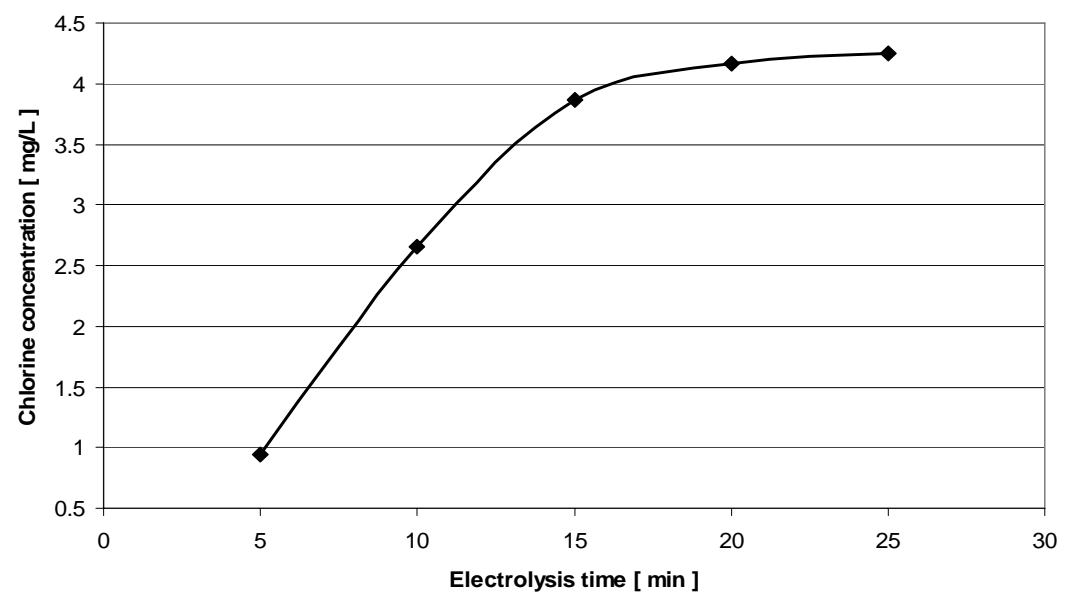

Fig. 3. Electrolytic production of chlorine using a laboratory electric power source.

\subsection{Study of chlorine production using a photovoltaic panel}

In a next series of experiments a hermetic electrolytic cell was connected to a photovoltaic panel which served as a source of electric energy. Irregularities of this energy source (dependence on intensity of solar irradiation) were compensated by rheostat. The constant voltage $6 \mathrm{~V}$ and $0.6 \mathrm{~A}$ current were used similarly as in the case of laboratory electric power source. Results of water chlorination are presented in Fig. 4. It was found that maximal concentration of chlorine in water was $4.2 \mathrm{mg} / \mathrm{dm}^{3}$ which was achieved after 25 minutes of electrochemical chlorine production. Both energy sources provide the maximal concentration of chlorine in water $4.2 \mathrm{mg} / \mathrm{dm}^{3}$ after 25 minutes of electrolysis. However, in case of PV panel the initial chlorine concentration is about 2.5 times higher. Measurement of intensity of solar irradiation represents Figure 5.

From the kinetics of chlorine production it was calculated that the tested hermetic cell connected to the photovoltaic panel (nominal output $50 \mathrm{~W}$ and solar irradiation 
$380-550 \mathrm{~W} / \mathrm{m}^{2}$ ) can provide $0.3 \mathrm{mg}$ of chlorine per minute what represents amount of chlorine sufficient for disinfection of approximately 40001 water per day.

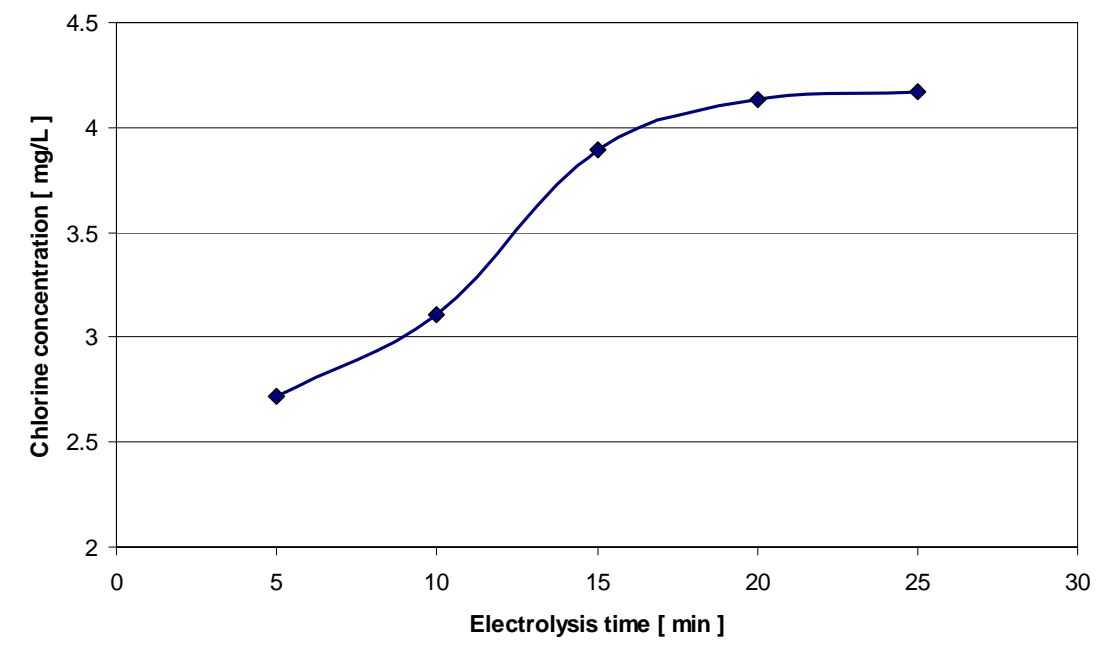

Fig. 4. Electrolytic production of chlorine using a photovoltaic panel.

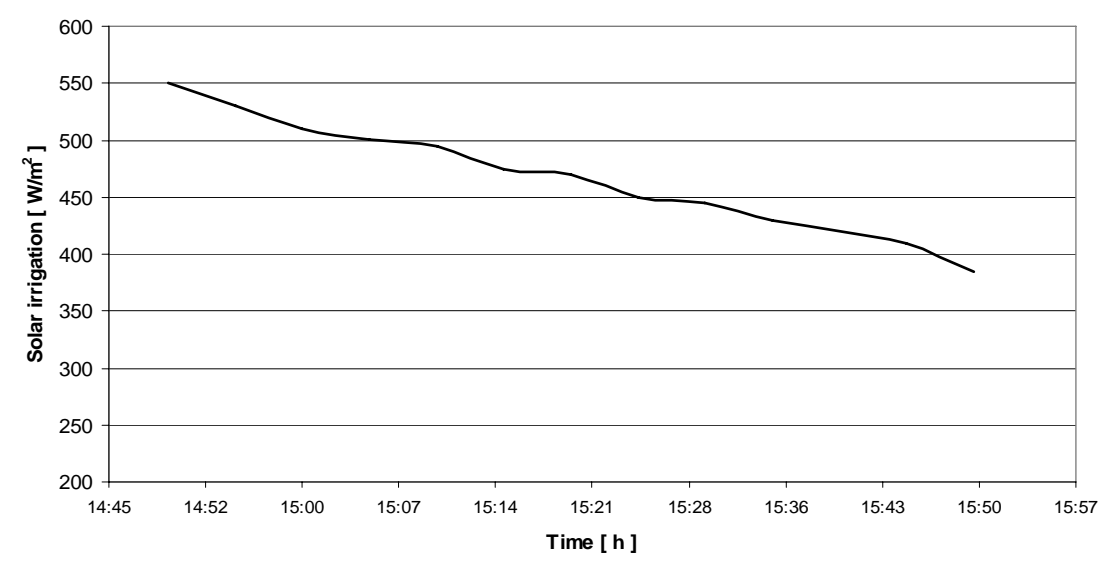

Fig. 5. Solar irradiation during chlorination of water using a photovoltaic panel.

\section{Conclusion}

It was found that PV panel can be used as an alternative of a laboratory electric power source to provide electric energy for an electrolytic chlorine production in a hermetic cell. PV panel can be recommended, after some improvements and economic calculations, for practical application. 
Acknowledgement: This work was supported by projects under the contract No. VEGA 1/0798/08, Development and utilization of small hydroenergetic power source combined with solar systems in machine technologies.

\section{References}

APPLEYARD, S.: Assessing the use of simple dye-sensitized solar cells for drinking water chlorination by communities with limited resources. Renew. Energ., 34, 2009, 1651-1654

BARTRAM, J., MIA, K. L., LENTON, R., WRIGHT, A.: Focusing on improved water and sanitation for health. Lancet, 365, 2005, 810-812

ĎURICOVÁ, I., HOSTIN, S., ONDRUŠKA, M., MICHALÍKOVÁ, A., GERULOVÁ, K.: The catalogue of projects, Solar laboratory, MTF STU Trnava, 2008, 58 pp., ISBN 978-80-969443-8-5

JONSON, J. D., OVERBY, R.: Stabilized neutral orthotolidine, SNORT, colorimetric method for chlorine. Anal. Chem., 41, 1969, 1744-1750

REED, R.H.: The inactivation of microbes by sunlight, solar disinfection as a water treatment process. Adv. Appl. Microbiol., 54, 2004, 333-365

VERČIMÁKOVÁ, K., RYBÁR, R., TROJAN, P.: Utilization of UV radiation for water disinfection in solar reservoirs. Acta Mont. Slov., 13, 2008, 343-349 